\title{
ФУНКЦІЇ АДМІНІСТРАТИВНО-ПРАВОВОГО РЕГУЛЮВАННЯ ДЕРЖАВНОЇ ПОЛІТИКИ У СФЕРІ БАНКРУТСТВА В УКРАЇНІ
}

Сарнацький М. А.

Статтю присвячено дослідженню функцій адміністративно-правового регулювання державної політики у сфері банкрутства в Україні. Наголошено, що держава, з одного боку, гарантує кожному право на підприємницьку діяльність, а з іншого - нормами Господарського кодексу України визначає підприємництво як самостійну, ініціативну, систематичну, на власний ризик господарську діяльність, що здійснюється суб'єктами господарювання (підприємцями) з метою досягнення економічних і соціальних результатів та одержання прибутку. При цьому зазначається, що кожен суб'єкт, зорієнтувавши свою підприємницьку діяльність на досягнення економічних і соціальних результатів та одержання прибутку, бере на себе й усі ризики своєї діяльності. 3 огляду на те, що наслідки банкрутства загалом $\epsilon$ негативними для України, зроблено висновок про нагальну потребу формування дієвого механізму адміністративно-правового регулювання сфери підприємництва.

Ключові слова: банкрутство, боржник, функції адміністративно-правового регулювання, процедура банкрутства, державна політика у сфері банкрутства.

Статья посвящена исследованию функций административно-правового регулирования государственной политики в сфере банкротства в Украине. Отмечено, что государство, с одной стороны, гарантирует каждому право на предпринимательскую деятельность, а с другой - нормами Хозяйственного кодекса Украины определяет предпринимательство как самостоятельную, инициативную, систематическую, на собственный риск хозяйственную деятельность, которая осуществляется субъектами ведения (предпринимателями) хозяйства с иелью достижения экономических и социальных результатов и получения прибыли. При этом отмечается, что каждый субъект, сориентировав свою предпринимательскую деятельность на достижение экономических и социальных результатов и получение прибыли, берет на себя и все риски своей деятельности. Ввиду того, что последствия банкротства в целом являются негативными для Украины, сделан вывод о неотложной потребности формирования действенного механизма административно-правового регулирования сферы предпринимательства.

Ключевые слова: банкротство, должник, функции административно-правового регулирования, процедура банкротства, государственная политика в сфере банкротства.

The article is devoted to the study of the functions of administrative and legal regulation of state bankruptcy policy in Ukraine. It is noted that the state on the one hand guarantees the right to entrepreneurial activity, protection of competition in the control over the prevention of abuse of dominant market position, and on the other, the norms of the Economic code of Ukraine, defines entrepreneurship as independent, initiative, systematic, at own risk economic activity exercised by economic entities (entrepreneurs) to achieve economic and social results and profit.

Сарнацький М. А., 2019
At the same time, it is noted that each entity, focusing its business activities on achieving economic and social results and making a profit, assumes all the risks of its activities. Taking into account that the consequences of bankruptcy are generally negative for Ukraine, in particular, the number of enterprises decreases, which leads to a decrease in the supply of goods, works or services, the unemployment rate increases and payments to the unemployed, tax revenues to the state budget decrease, etc., it is concluded that there is an urgent need to form an effective mechanism for administrative and legal regulation of the sphere of entrepreneurship, which includes the content of the state policy in the field of bankruptcy in Ukraine.

The author notes that the functions, together with its inherent method of legal regulation of public relations, determine the social purpose of law and show what subject activities, relationships are organized and regulated by law. Therefore, it is proved that legal functions express the direction of the influence of law on public relations, so the indicator of their implementation is the socio-economic and other consequences that occurred as a result of the law. Thus, the functions show an active role of law. In particular, the regulatory impact on the sphere of bankruptcy is performed by four main functions: health-improving, satisfying, preventive, and punitive. Despite the fact that every scientific argumentative type of classification of the functions of regulation has the right to exist, according to the author of the study, as the most optimal among all the existing in literature approaches to their classification is the traditional division of functions of administrative-legal regulation on the General and specific, given that all of these kinds of functions, but common, in fact, are specialized, showing a certain specific activities of the state in the sphere of administrative legal regulation.

Key words: bankruptcy, debtor, functions of administrative and legal regulation, bankruptcy procedure, state policy in the field of bankruptcy.

Постановка проблеми та їі актуальність. Становлення та розбудова української держави формує нагальну потребу наукового переосмислення підходів до публічного управління загалом й адміністративно-правового регулювання сфери підприємництва зокрема. Адже, закріпивши в ст. 42 Конституції України право на підприємницьку діяльність, яка не заборонена законом, держава забезпечує захист конкуренції у підприємницькій діяльності. При цьому не допускаються зловживання монопольним становищем на ринку, неправомірне обмеження конкуренції та недобросовісна конкуренція. Види і межі монополії визначаються законом. Держава захищає права споживачів, здійснює контроль за якістю і безпечністю продукції та усіх видів послуг і робіт, сприяє діяльності громадських організацій споживачів [1]. Як бачимо, держава, з одного боку, гарантує кожному право на підприємницьку діяльність, захист конкуренції і при цьому контроль за недопущенням зловживання монопольним становищем на ринку, а з іншого - нормами Господарського кодексу України визначає підприємництво як самостійну, ініці- 


\section{Економічна безпека держави: теорія і практика}

ативну, систематичну, на власний ризик господарську діяльність, що здійснюється суб'єктами господарювання (підприємцями) з метою досягнення економічних і соціальних результатів та одержання прибутку [2]. При цьому зміст господарських норм свідчить, що кожен, зорієнтувавши свою підприємницьку діяльність на досягнення економічних і соціальних результатів та одержання прибутку, бере на себе й усі ризики своєї діяльності. А це своєю чергою кореспондується з можливістю настання внутрішніх та зовнішніх факторів, що потягнуть за собою визнання господарським судом неспроможності боржника відновити свою платоспроможність за допомогою процедур санації та мирової угоди і погасити встановлені у порядку, визначеному цим Законом, грошові вимоги кредиторів не інакше як через застосування ліквідаційної процедури. Тобто йдеться про банкрутство.

Метою статті $€$ дослідження функцій адміністративно-правового регулювання державної політики у сфері банкрутства в Україні як передумови формування ефективної соціально-орієнтованої економіки.

Виклад основного матеріалу. Процес банкрутства може бути ініційований або особою-боржником (добровільне банкрутство), або будь-ким з кредиторів, якому боржник не може виплатити борг (вимушене банкрутство). Справи про банкрутство підвідомчі господарським судам і розглядаються ними за місцезнаходженням боржника. Доти, доки банкрут не розрахується з боргами, його фінансова діяльність жорстко обмежена.

Як наголошують дослідники, кількість підприємств, що знаходяться на межі банкрутства, в України зростає, а тенденції банкрутства поширюються не лише на окремих суб'єктів господарювання, а й на галузі загалом. Кількість підприємств-банкрутів у 20062011 роках постійно зростала, причому перше найбільш активне зростання їх кількості відбулося в 2006 році (на 2892 підприємства). Надалі кількість банкрутств також зростала, і в 2007 році їх чисельність збільшилася ще на 3109 підприємств. Проте в наступному 2008 році кількість банкрутств скоротилася на 2454 випадки. В наступні роки банкрутство відзначилось певним стрибком вниз, а потім знову зросло, що пояснюється відсутністю стабільної політики, світовою кризою, нестачею інвестиційних надходжень та неспроможністю вести антикризову політику. Згідно з даними статистики протягом 2010 року порушено 14642 справ про банкрутство підприємств різної форми власності, тоді як у 2009 році ця кількість складала 15642 справ, тобто відбулось певне зменшення. 3 цих справ про банкрутство державних підприємств та підприємств 3 державною часткою понад 25\% порушено на $6 \%$ більше, ніж за 2009 рік (204 та 217 відповідно) [3].

На кінець 2011 року загальна кількість підприємств, які перебували у процедурах банкрутства, становить 17 178, що на 2536 більше, ніж у 2010 році, та на 1536 - ніж у 2009 році. Із 502 припинених у 2011 році справ про банкрутство підприємств лише 9 суб'єктів господарювання використали механізм санації з метою відновлення платоспроможності боржника, 452 підприємства було ліквідовано. Загалом за 2006-2011 роки кількість підприємств, що збанкрутували, зросла на 4878 одиниць [4].

Не $\epsilon$ кращою і статистика останніх років. Так, судом касаційної інстанції за 2017 рік було розглянуто близько
5 тисяч господарських справ, серед яких п'яту частину спорів склали справи про банкрутство, а це свідчить, що справи про банкрутство займають значну частину у структурі господарських спорів.

Загалом, як наголошує очільник Касаційного Господарського Суду у складі Верховного Суду, «на жаль, якщо брати всі господарські суди, то загальна кількість спорів дещо зменшилася. Це відбулося через стан економіки у державі. Нині ми простежуємо пряму кореляцію: менш активна економіка - менше судових спорів. Хоча в цьому (2019) році $\epsilon$ невеличке пожвавлення, і кількість справ потрохи зростає. Дуже хочеться сподіватися, що економічний стан у державі покращується. Проте поспішати з висновками не будемо, оскільки ця тенденція простежується тільки останні 3-4 місяці» [5].

Беручи до уваги вищезазначене, вітчизняні вчені наголошують, що наслідки банкрутства загалом $\epsilon$ негативними для України: зменшується кількість підприємств, що призводить до зменшення пропозиції товарів, робіт чи послуг, зростає рівень безробіття і виплат безробітним, зменшуються податкові надходження до держбюджету і так далі [7].

Саме тому $\epsilon$ нагальна потреба у формуванні дієвого механізму адміністративно-правового регулювання сфери підприємництва, що включає в себе зміст державної політики у сфері банкрутства в Україні. Аби дослідити зміст механізму адміністративно-правового регулювання державної політики у сфері банкрутства, на нашу думку, слід з'ясувати функції та принципи такого регуляторного впливу на сферу підприємництва.

Саме поняття «функція» походить 3 латинської й означає діяльність. Оскільки у нашому випадку йдеться про управлінський вплив публічної влади на сферу підприємництва, ми розглядаємо категорію «функція» через призму управління.

У юридичній літературі поняття «функції управління» має досить багатогранне тлумачення. Як наголошує професор А.І. Берлач, у функціях будь-якої науки, в тому числі й адміністративного права, виявляються ті завдання, які вона повинна вирішувати, іiї соціальне призначення. На сучасному етапі невирішеним залишається питання єдиного підходу до видової класифікації функцій державного управління [7, с. 146].

На думку А. Мельник, функції державного управління - це специфічні за предметом, змістом і засобом забезпечення цілісні управляючі впливи держави [8, с. 87].

Своєю чергою В. Малиновський трактує функцію як спеціалізований вид управлінської діяльності, який пов'язаний $з$ певною метою - запланованим результатом. Оскільки мета $\epsilon$ ідеальним прогнозуванням результату управлінської праці, то саме визначення завдання і $\epsilon$ першим кроком у досягненні мети. Природним посередником між завданням і метою виступає функція управління як практична діяльність у реалізації поставлених цілей [9].

Професор І.П. Голосніченко вважає функцію державного управління основним напрямом управлінської діяльності, за допомогою якого виконуються державні завдання та досягається мета, яку ставить законодавець у нормах адміністративного права [10, с. 19].

Функцію державного управління як частину управлінської діяльності держави, яку здійснюють на основі закону чи іншого правового акта органи виконав- 
чої влади притаманними їм методами для виконання завдань державного управління, визначає професор Ю.П. Битяк [11, с. 126].

Проаналізувавши вищезазначені думки вчених, маємо змогу констатувати, що попри існування різноманітних визначень поняття функцій, фактично в більшості з них функції пов'язуються саме із регулюючою діяльністю. Такою $€$, зокрема, позиція Ю. Козлова, який, слушно вважаючи вид регулюючої діяльності основною ознакою функцій адміністративно-правового регулювання, визначає їх як найбільш типові, однорідні та чітко виражені види (напрями) відповідної діяльності, що служать інтересам досягнення цілей регулюючого впливу [12, с. 3].

На основі аналізу поглядів науковців у галузі адміністративного права вітчизняна дослідниця Л.В. Сенченко дійшла висновку, що функції адміністративно-правового регулювання - це основні види адміністративно-правової діяльності суб'єкта, пов'язані із його впливом на об'єкти регулювання, що зумовлені досягненням мети та підпорядковані вирішенню конкретних завдань $[13$, с. 75$]$.

Питання класифікації функцій адміністративно-правового регулювання $\epsilon$ не новим для дослідників державного управління чи адміністративного права. Однак думки більшості з вчених сходяться на тому, що функції управління варто поділяти на загальні (основні) та особливі (спеціальні).

Своєю чергою загальні управлінські функції слід розглядати як універсальні види діяльності суб'єктів регулювання, в межах яких вирішуються найбільш типові завдання, що мають відношення до всіх суб'єктів і об'єктів. Серед таких варто зазначити прогнозування, планування, організацію, керівництво, координацію, контроль та облік. В. Малиновський схематично поділяє загальні функції державного управління на чотири категорії: адміністративно-політичні, економічні, соціальні та культурно-освітні функції [9].

Поряд із загальними виділяють спеціальні функції, які характеризуються тим, що забезпечують врахування особливостей конкретного суб'єкта та об'єкта його впливу і розрізняються залежно від особливостей галузей (підгалузей), підприємств, установ, організацій тощо.

Вітчизняні дослідники адміністративно-правового регулювання у сфері банкрутства зазначають, що функції, разом з властивим їй методом правового регулювання суспільних відносин і галузевими принципами, визначають соціальне призначення права й показують, яка предметна діяльність, які відносини організуються і регулюються правом.

Саму тому правові функції виражають спрямованість впливу права на суспільні відносини, тому показником їх реалізації служать соціально-економічні та інші наслідки, що відбулися в результаті дії права. Таким чином у функціях проявляється активна роль права.

Регуляторний вплив на сферу банкрутства виконує чотири основних функції: оздоровчу, задовольняючу, превентивну, каральну.

Зокрема, оздоровча функція виявляється у можливості застосування до неплатоспроможного боржника тих процедур банкрутства, які насамперед спрямовані на оздоровлення фінансового становища боржника зокрема та національної економіки загалом.
Задовольняюча функція виражається у тому, що стосовно майна боржника вводиться особливий правовий режим з метою здійснення з цього майна пропорційного та розмірного задоволення вимог кредиторів.

Своєю чергою превентивна функція проявляється у тому, що спонукає суб'єктів господарювання ефективно та сумлінно вести свої справи та запобігати стану неплатоспроможності. Розуміння того, що за умови нераціонального керівництва своїми справами суб'єкт господарювання може позбавитися своєї справи, доброго ім'я та бути втягнутий в довготривале судове провадження, $\epsilon$ значним економічним стимулом, який спонукає суб'єкта господарювання докладати максимум зусиль на підтримку належного економічного стану своєї справи.

I нарешті, каральна функція виявляється у тих обставинах, за наявності яких неплатоспроможній боржник, котрий не в змозі погасити вимоги кредиторів і щодо якого порушено провадження у справі про банкрутство, суттєво обмежується у своїх правах та відсторонюється від свого майна - позбавляється права управляти належним йому майном та, відповідно, своєю справою. Свій нормативний вираз вказані функції одержують у нормативних приписах у вигляді цілей правового регулювання [14].

Незважаючи на те, що кожен науково аргументований тип класифікації функцій регулювання має право на існування, найбільш оптимальним серед усіх існуючих у спеціальній літературі підходів до їх класифікації $\epsilon$ традиційний розподіл функцій адміністративно-правового регулювання на загальні та особливі, враховуючи, що всі перелічені різновиди функцій, окрім загальних, по суті, $\epsilon$ спеціалізованими, являючи собою ті чи інші конкретні види діяльності держави у сфері адміністративно-правового регулювання.

Як нам видається, має право на існування й інший підхід щодо класифікації функцій адміністративно-правового регулювання у сфері банкрутства. 3 огляду на це доречним $є$ проведення систематизації функції адміністративно-правового регулювання державної політики у сфері банкрутства за найбільш типовою класифікацією функцій і поділ їх на загальні та спеціальні функції.

Так, зокрема, загальними функціями адміністративно-правового регулювання державної політики у сфері банкрутства $€$ :

- прогнозування, що передбачає процес наукового передбачення майбутнього стану певних явищ і їх зміну під впливом управлінської діяльності. Важливість цієї функції полягає в тому, що вона дозволяє зазирнути в майбутнє, чим надає всьому регуляторному впливу достатньої наукової обґрунтованості та перспективності. Як результат функції маємо прогноз, тобто пропозицію щодо здійснення конкретного виду діяльності, необхідного для успішного виконання інших функцій адміністративно-правового регулювання (планування, організації, контролю тощо);

- планування, що передбачає формування між його елементами взаємозв'язку та проявляється через завдання, які становитимуть його сутнісний зміст. Окрім цього складника, у плані фіксується термін, протягом якого він діє (так званий плановий період), характеристика очікуваних і потенційно здійснених результатів, обґрунтування визначених цілей, оцінка проведених заходів за звітний період та конкрет- 


\section{Економічна безпека держави: теорія і практика}

ні практичні завдання. Як приклад вираження функції планування можна представити зміст ст. 5 Кодексу України з процедур банкрутства, якою передбачено, що санація боржника до відкриття провадження у справі про банкрутство здійснюється відповідно до плану санації боржника до відкриття провадження у справі про банкрутство (далі - план санації). У плані санації обов'язково зазначається розмір вимог кожного класу кредиторів, які були б задоволені у разі введення процедури ліквідації боржника [15];

- координація, що забезпечує узгодження діяльності систем управління. Завдяки координуванню узгоджують дії керівників не тільки всередині управлінської ланки, а й дії керівників інших управлінських структур. Так, згідно зі ст. 96 Кодексу України з процедур банкрутства Кабінет Міністрів України вживає заходів для запобігання банкрутству державних підприємств та підприємств, у статутному капіталі яких частка державної власності перевищує 50 відсотків, визначає оптимальні шляхи відновлення їх платоспроможності та координує дії відповідних органів виконавчої влади [15];

- організації, пов'язана зі створенням організаційного механізму, зокрема, іiі особливість полягає в тому, що це єдина функція, яка забезпечує взаємозв'язок та ефективність усіх інших функцій. Зміст функції організації включає створення органів адміністративно-правового регулювання державної політики у сфері банкрутства, формування структури апарату, підрозділів, встановлення зв'язків між управлінськими структурами, підбір та розстановку кадрів тощо. Так, відповідно до ст. 68 Кодексу України з процедур банкрутства продаж майна боржника на аукціоні відбувається в електронній торговій системі. Порядок функціонування електронної торгової системи, організації та проведення електронних аукціонів, визначення розміру, сплати, повернення гарантійних внесків та сплати винагороди операторів електронних майданчиків затверджується Кабінетом Міністрів України [15];

- контрольна, визначає відповідність процесу функціонування об'єкту адміністративно-правового регулювання прийнятим управлінським рішенням, виявляє результати впливу суб'єкта на об'єкт, перевіряє якість виконання управлінських рішень. За допомогою контролю виокремлюються напрями корегування дії об'єкту адміністративно-правового регулювання, способи впливу на нього з метою забезпечення якісного виконання управлінських рішень. Нормами ст. 20 Кодексу України з процедур банкрутства передбачено, що контроль за діяльністю арбітражних керуючих здійснюється державним органом з питань банкрутства або саморегулівною організацією арбітражних керуючих. Державний орган з питань банкрутства здійснює контроль за діяльністю арбітражних керуючих шляхом проведення планових і позапланових перевірок у встановленому ним порядку [15].

- обліку, що пов'язана зі збиранням, переданням, зберіганням і обробкою даних; реєстрацією та групуванням відомостей про діяльність системи управління; наявністю та витратами ресурсів. Так, згідно з ч. 5 ст. 50 Кодексу України з процедур банкрутства керуючий санацією зобов'язаний забезпечити ведення боржником бухгалтерського обліку і статистичного звіту та фінансової звітності [15];

- інформаційного забезпечення, забезпечує функціонування управлінського процесу. Так, зокрема, кандидатура арбітражного керуючого для виконання повноважень розпорядника майна або керуючого реструктуризацією, згідно зі ст. 28 Кодексу України з процедур банкрутства, визначається судом шляхом автоматизованого відбору із застосуванням Єдиної судової інформаційно-телекомунікаційної системи з числа арбітражних керуючих, внесених до Єдиного реєстру арбітражних керуючих України, за принципом випадкового вибору [15].

Що стосується спеціальних функцій, що відображають особливості адміністративно-регулюючого впливу конкретного суб'єкта регулювання на державну політику у сфері банкрутства, то такими є:

1. Здійснення систематичного аналізу внутрішніх та зовнішніх чинників стану та перспектив економічного розвитку суб'єктів підприємництва. Завчасне визначення передумов виникнення стану банкрутства (неплатоспроможності) дозволяє вже на первинних етапах пом'якшити чи не допустити виникнення його негативних наслідків для суб'єкта підприємництва.

2. Розробка, обґрунтування та реалізація плану заходів санації боржника. У плані санації обов'язково зазначається розмір вимог кожного класу кредиторів, які були б задоволені у разі введення процедури ліквідації боржника.

3. Коригування розподілу отриманих від реалізації майна коштів, затвердження звіту про такий розподіл зборами кредиторів та подання такого звіту до суду.

4. Співпраця з іноземними судами та керуючими іноземною процедурою банкрутства здійснюється шляхом:

- вчинення дій в іноземній державі;

- передачі інформації іноземному суду чи керуючому іноземною процедурою банкрутства, якщо передача такої інформації не заборонена законом;

- координації дій з управління активами та господарською діяльністю боржника;

- координації дій з надання судової допомоги під час здійснення проваджень у справах про банкрутство стосовно одного й того самого боржника.

5. Стабілізація економічного стану боржника, контроль за правильністю та своєчасністю справляння податків і зборів (обов'язкових платежів), страхових внесків на загальнообов'язкове державне пенсійне та інше соціальне страхування.

Висновки. Беручи до уваги думки та здобутки вчених-адміністративістів та фахівців у галузі господарського права щодо визначення і класифікацій функцій адміністративно-правового регулювання та проаналізованих особливостей суспільних відносин у сфері банкрутства, можна сформулювати визначення поняття вказаних функцій як зовнішній прояв властивостей суб'єктів регулювання, який характеризується самостійністю, здійснюється специфічними методами залежно від певного об'єкту регулювання з метою досягнення певних результатів у нормалізації процесів підприємницької діяльності. 


\section{Література}

1. Конституція України: прийнята на п'ятій сесії Верховної Ради України 28 червня 1996р. Відомості Верховної Ради України. 1996. № 30. Ст. 141.

2. Господарський кодекс України від 16 січня 2003 р. (BBP), 2003, № 18, № 19-20, № 21-22, ст.144)

3. Мігорян М. «Феномен банкрутства підприємств в Україні». Матеріали всеукраїнської студентської інтернет-конференції «Стратегії економічного розвитку підприємств в умовах глобалізації » від 25.04.2012p. URL: http: //conf-cv.at.ua/forum/85-826-1/.

4. Степанов О. Проблемні питання визначення недійсним правочині боржника у процедурі неспроможності (банкрутства). Право України. 2004, № 12.

5. Заступник Голови Верховного Суду, голова Касаційного господарського суду Богдан Львов: «Характер судових спорів зумовлений рівнем розвитку економіки». «Закон і Бізнес». 2019. 03 червня. URL: https://zib.com.ua/ ua/137893-golova_kgs_bogdan_lvov_harakter_sudovih_ sporiv_zumovleniy_ri.html.

6. Коваленко О.В., Скляренко К.В. Банкрутство підприємств в Україні: причини та наслідки. URL: www.zgia.zp.ua. 2013. C. 66-67.

7. Берлач А.І. Адміністративне право України: [навч. посіб. для дист. навч.]. Київ : Ун-т «Україна», 2005. 472 с.

8. Державне управління: [навч. посіб.] / А.Ф. Мельник, О.Ю. Оболенський, А.Ю. Васіна, Л.Ю. Гордієнко; за ред. А.Ф. Мельник. Київ : Знання-Прес, 2003. 343 с.
9. Малиновський В.Я. Державне управління: Навчальний посібник. Луцьк : Ред.-вид. відд. «Вежа» Вол. держ. ун-ту ім. Лесі Українки, 2000. 558 с.

10. Адміністративне право України: основні поняття : навч. посібник / [І.П. Голосніченко, М.Ф. Стахурський та Н.І. Золотарьова]. Київ : ГАН, 2005. 232 с.

11. Адміністративне право України: підручник / [Ю.П. Битяк, В.М. Гаращук, О.В. Дьяченко та ін.]; за ред. Ю.П. Битяка. Київ : Юрінком Інтер, 2006. 544 с.

12. Козлов Ю. Государственное управление при переходе от планового хозяйства к рыночному. Проблемы теории и практики управления. 1998. № 1. С. 2-5.

13. Сенченко Л.В. Адміністративно-правове регулювання демографічної політики в Україні. Дисертація на здобуття наукового ступеню кандидата юридичних наук за спеціальністю - адміністративне право і процес; фінансове право; інформаційне право, Відкритий міжнародний університет розвитку людини «Україна» - Київ, 2011. С. 75.

14. В. Радзивілюк. Метод, принципи та функції права банкрутства (неспроможності). Вісник Київського національного університету імені Тараса Шевченка. Юридичні науки. 2010, № 82, С. 24.

15. Кодекс України з процедур банкрутства від 18 жовтня 2018 р. ВBP, 2019,№ 19, ст.74.

Сарнацький М. А., аспірант кафедри адміністративного права Київського національного університету імені Тараса Шевченка 